\title{
The Influence of Feeding Level on Growth Performances of European Catfish (Silurus glanis L., 1758) Juveniles under Recirculating Water Conditions
}

\author{
Iulia GRECU ${ }^{1 *}$, Lorena DEDIU ${ }^{2}$, Angelica DOCAN ${ }^{1}$, Victor CRISTEA ${ }^{2}$ \\ ${ }^{1}$ Faculty of Food Science and Engineering, ${ }^{2}$ Cross-Border Faculty \\ University "Dunarea de Jos" of Galati, Romania, 47 Domneasca Street, 800008, Galaţi, Romania \\ *corresponding author: iulia.grecu@ugal.ro
}

Bulletin UASVM Animal Science and Biotechnologies 76(2)/ 2019

Print ISSN 1843-5262; Electronic ISSN 1843-536X

DOI:10.15835/buasvmcn-asb: 0017.19

\begin{abstract}
The study was carried out with one summer-old Silurus glanis juveniles, having the mean size $23.04 \pm 2.05 \mathrm{~cm}$ and weight $73.84 \pm 19.12 \mathrm{~g}$, reared in recirculating water condition, in order to assess the impact of feeding level on growth performances and body size variation of fish. Two feeding levels were tested (R1=1.5\% BW/day and $\mathrm{R} 2=2.5 \%$ BW/day), in duplicate, during 6 weeks, and the biomass gain (BG), feed conversion ratio (FCR), specific growth rate (SGR), protein efficiency ratio (PER), morphometric relationship between length-weight (LWR) and coefficient of variation (CV) were assessed. Data revealed that the overall mean weight of the biomass was doubled during the trial, from $14.92 \mathrm{~kg}$ to $31.17 \mathrm{~kg}$, and the body growth significantly increases with the increment of the feeding rate (13.48 $\mathrm{kg}$ in R1 and $17.70 \mathrm{~kg}$ in R2), underlying the good potential of the species, at this life stage, for fast-growing under intense conditions. The calculated SGR in R1 was 1.43\%/day and in R2, significantly higher, as $2.05 \%$ /day, for the almost similar values of FCR $(0.74 \mathrm{~g} / \mathrm{g})$ and PER $(2.50 \mathrm{~g} / \mathrm{g})$ recorded between the treatments.
\end{abstract}

Keywords: Silurus glanis, growth performance, fish condition, feeding rate

\section{Introduction}

The growth of the European catfish in controlled environmental conditions by treating and recirculating water, like recirculating aquaculture systems (RAS), is a progressive challenge for aquaculture in Romania, at least from the perspective of business that can bring profit to investors. The optimization of production in a recirculating system implies the simultaneous satisfaction of some preconditions, particularly maintaining good water quality for rapid fish growth while implementing efficient feeding management (Timmons et al., 2002). Proper feed management keeps an optimum environment for fish biomass at the minimum cost production taking into account that the cost of feed is considered the most dominant cost (40-50\%) (Bregnballe, 2015; Silva and Anderson, 1995) with significant impact on the fish farming's feasibility. Therefore, adjusting the optimum feeding rate, according to the fish species, fish size and rearing system, is a goal to achieve in a RAS (Timmons et al., 2002). Practical aspects of growth rate and feeding regime of Silurus glanis species in intensive conditions are increasingly being investigated in the last years (Hilge, 1985; Bekcan et al., 2006; 
Placinta et al., 2012; Florczyk et al., 2014; Havasi et al., 2015) showing a robust and easy-adaptative fish (Linhart et al., 2002) as long the water quality is maintaining in optimal intervals. In general, these are important arguments for fish being raised in RAS because high growth rate increases production turnover as soon as fish reach the market size. Thus, the growth parameters of this voracious fish, applying different feeding levels, are presented in this paper, in order to know more about the feeding management of the European catfish juveniles in the recirculating water condition.

\section{Materials and methods Experimental design}

The experiment was carried out within an experimental recirculating system of the Aquaculture division in "Dunărea de Jos" University of Galati, described in previous papers (Vasilean et al., 2009; Mocanu et al., 2011), on one-summer old juveniles of European catfish with an initial mean weight of $73.84 \pm 19.12 \mathrm{~g}$ and length $23.04 \pm 2.05$ $\mathrm{cm}$. The fish were randomly distributed into the four rearing basins of the recirculating system (volume of $0.300 \mathrm{~m}^{3} /$ unit), thus the fish biomass was distributed approximately equally between basins (B1-47 fish, B2-51 fish, B3-51fish, B4-53 fish).

During the trial, the juveniles were fed with two daily feeding rates, each one being tested in duplicate: R1 - $1.5 \% \mathrm{BW} /$ day for the basins $\mathrm{B} 1 \& \mathrm{~B} 2$ and $\mathrm{R} 2-2.5 \% \mathrm{BW} /$ day for the basins B3\&B4, with extruded pellets represented by Nutra 0 (commercial diet for salmonids) with the composition presented in Tab. 1. The daily amount used for fish feeding was manually administrated in three equal meals $(08: 00,12: 00$ and 16:00).

Table 1. Biochemical composition of the Nutra 0 extruded feed

\begin{tabular}{cc}
\hline Crude protein & $54 \%$ \\
\hline Crude fat & $18 \%$ \\
\hline Crude cellulose & $0.6 \%$ \\
\hline Ash & $10 \%$ \\
\hline Phosphorous & $1.45 \%$ \\
\hline Vitamin A & $14000 \mathrm{UI} / \mathrm{kg}$ \\
\hline Vitamin D3 & $2300 \mathrm{UI} / \mathrm{kg}$ \\
\hline Vitamin E & $250 \mathrm{mg} / \mathrm{kg}$ \\
\hline Vitamin C & $500 \mathrm{mg} / \mathrm{kg}$ \\
\hline Copper sulphate & $8.5 \mathrm{mg} / \mathrm{kg}$ \\
\hline
\end{tabular}

During those 6 weeks of experimental period, fish were exposed to the natural photoperiod and the welfare state (swimming, feeding behavior, sanitary problems) was monitored. The water physicochemical parameters during the experiment were recorded (daily, for temperature and dissolved oxygen - determined with Hanna oxygen meter model HI 9142, as well as for $\mathrm{pH}$ determined with Hanna pH meter model HI 81143; weekly, for nitrogen compounds - measured with Merck photometer model Spectroquant Nova 400 using specific manufactured Merck test kits).

\section{Production performances}

The fish were weighed and measured, individually, to the nearest $1 \mathrm{~g}$ and $0.5 \mathrm{~cm}$. The biometry was performed on fish after $24 \mathrm{~h}$ stop feeding, in anesthetic conditions (2-phenoxyethanol-0.3 mL/L water). For verifying and control of the growth performances induced by those two feeding ratios, at the beginning of the experiment, 8 fish/basin were individually tagged. The production parameters were calculated by classical methods, such as:

Total biomass production

Total biomass gain: $\mathrm{BG}=\mathrm{Bf}-\mathrm{Bi}(\mathrm{g} / \mathrm{basin})$, where Bi-total initial biomass, Bf-total final biomass;

Food conversion ratio: $\mathrm{FCR}=\mathrm{FI} / \mathrm{BG}$ (g/g), where FI-feed intake ( $\mathrm{g} /$ basin), BG-total biomass gain (g/basin);

Protein efficiency ratio: PER=BG/PI (g/g), where BG-total biomass gain (g/basin), PI-protein intake of our food (g).

Individual fish growth

Fish weight gain: $W G=W f-W i(g)$, where $W i-$ initial fish mean weight, Wf-final fish mean weight;

Fish condition: $\mathrm{W}=\mathrm{axL} \mathrm{L}^{\mathrm{b}}$, (length-weight relationship), where the coefficient " $a$ " is the regression intercept and " $b$ " is the regression slope obtained by linearization $[\operatorname{Ln}(\mathrm{W})=\operatorname{Ln}(\mathrm{a})+$ b $\ln (\mathrm{L})], \mathrm{W}=$ fish weight $(\mathrm{g}), \mathrm{L}=$ total length $(\mathrm{cm})$;

Specific growth rate: $S G R=[(\ln W f-$ $\operatorname{lnWi}) / t]^{* 100}$ (\%/day), where t-period time of feeding experiment (days)

\section{Data analysis}

The obtained values were statistically computed using SPSS Statistics 17.0 program and analyzed for the normality of distribution with the Kolmogorov-Smirnov Z test, for homogeneity of variances with Levene's test, for the comparison of the means with T-test (one sample, independent samples and paired samples) or one-way ANOVA. 
Table. 2. Growth performances of European catfish juveniles during the experiment

\begin{tabular}{ccccc}
\hline Experimental variants & \multicolumn{2}{c}{ Variant R1 (1.5\%) } & \multicolumn{2}{c}{ Variant R2 (2.5\%) } \\
\cline { 2 - 5 } Growth parameters & $\mathrm{B} 1$ & $\mathrm{~B} 2$ & $\mathrm{~B} 3$ & $\mathrm{~B} 4$ \\
\hline Initial fish mean weight - Wi $(\mathrm{g})$ & $78.40 \pm 25.52^{\mathrm{a}}$ & $72.35 \pm 15.08^{\mathrm{a}}$ & $73.88 \pm 19.10^{\mathrm{a}}$ & $71.17 \pm 15.45^{\mathrm{a}}$ \\
\hline Final fish mean weight $-\mathrm{Wf}(\mathrm{g})$ & $144.36 \pm 49.00^{\mathrm{b}}$ & $131.31 \pm 32.99^{\mathrm{b}}$ & $178.62 \pm 45.94^{\mathrm{c}}$ & $165.25 \pm 37.11^{\mathrm{c}}$ \\
\hline Fish weight gain - WG (g/fish) & 65.96 & 58.96 & 104.74 & 94.08 \\
\hline Total initial biomass - Bi (g) & 3685.00 & 3690.00 & 3768.00 & 3772.00 \\
\hline Total final biomass - Bf (g) & 6785.00 & 6697.00 & 8931.00 & 8758.00 \\
\hline Biomass gain - BG (g/basin) & 3100.00 & 3007.00 & 5163.00 & 4986.00 \\
\hline Survival $(\%)$ & 100.00 & 100.00 & 98.04 & 100.00 \\
\hline Note: Different letters between data denote significant differences $(\mathrm{p}<0.05)$. & \multicolumn{3}{c}{}
\end{tabular}

Significance was accepted at $\mathrm{p}<0.05$. Data are presented as mean \pm standard deviation $(\mathrm{M} \pm \mathrm{SD})$. Also, the size of heterogeneity within stock was assessed by the coefficient of variation (CV, \%).

\section{Results and discussions Water quality}

During the experiment, the water quality was kept in the optimum range, as a result of the daily replacement with clean water after its lost in the flushing process of removing the suspended solids from the mechanical filter (exchange rate did not exceed $10 \%$ of the total volume of water in the system). In consequence, water temperature varied in narrow limits, between $20.70-21.20^{\circ} \mathrm{C}$, not so far from the range recommended for specie's reproduction (21-23 ${ }^{\circ} \mathrm{C}$ ) by Woynarovich, and Horváth (1980) or for fingerlings growth $\left(25-28^{\circ} \mathrm{C}\right)$ by Hilge (1985). Due to supplementary aeration, the DO level was kept in an optimum range between $5.30-7.60 \mathrm{mg} / \mathrm{L}$, as well as the $\mathrm{pH}$ between 6.79-7.26 upH. The dynamics of the ammonium, nitrite and nitrate concentrations varied in the following intervals of minimum and maximum: 0.11-0.14 mg/L, 0.13$0.22 \mathrm{mg} / \mathrm{L}$ and $18.93-23.59 \mathrm{mg} / \mathrm{L}$, respectively. In consequence, under the described circumstances, the experimental recirculating system offered admissible conditions, from the water quality perspective, for growing the European catfish juveniles.

\section{Growth performances}

The series of values analyzed for each level (basin/experimental variant/total stock) of the initial and final fish mean weight showed no deviations from the normal distribution ( $p>0.05$ with K-S test) that permitted us to apply the parametric tests further. One-way ANOVA (for equal variances not assumed) applied at the beginning of the experiment, showed insignificant differences between all basins for the fish mean weight $(p=0.26>0.05)$. The T-test applied between the two feeding rate groups (equal variances assumed) confirmed the similarity of the fish mean weight $(\mathrm{p}=0.31>0.05)$, too.

After 42 days of the trial, the individual fish weight was doubled reaching an overall mean value of $155.08 \pm .45 .13 \mathrm{~g}$, underlying the good potential of the species for growing under intense conditions, at this life stage. At the end of the experiment, the final mean weight showed significantly higher values for the group fed with $2.5 \% \mathrm{BW} /$ day (T-test, equal variances assumed, $\mathrm{p}<0.001$ ). No variations between duplicates (intratreatment) were recorded, emphasizing the above somatic response. The results regarding growth performances in both experimental variants are summarized in Tab. 2.

The values of the SGR (specific growth rate) and FCR (food conversion ratio), considered as most important factors indicating the effectiveness of feed management and production performances in aquaculture, were determined for each feeding level (figure 1). The highest SGR was registered in variant fed with R2 (2.5\%) having a mean value with 43.21 $\%$ higher than R1 (1.5\%).

Since the individual SGR values computed for the tagged fish showed no significant difference from the basin's overall mean (T-test one sample, $\mathrm{p}>0.05$ ), that allowed us to apply statistical comparison between intra- and inter- experimental variants. There were no differences between the basins' SGRs belonging to the same feeding level (B1 and B2, respectively B3 and B4, T-test two sample, $p>0.05$ ), 


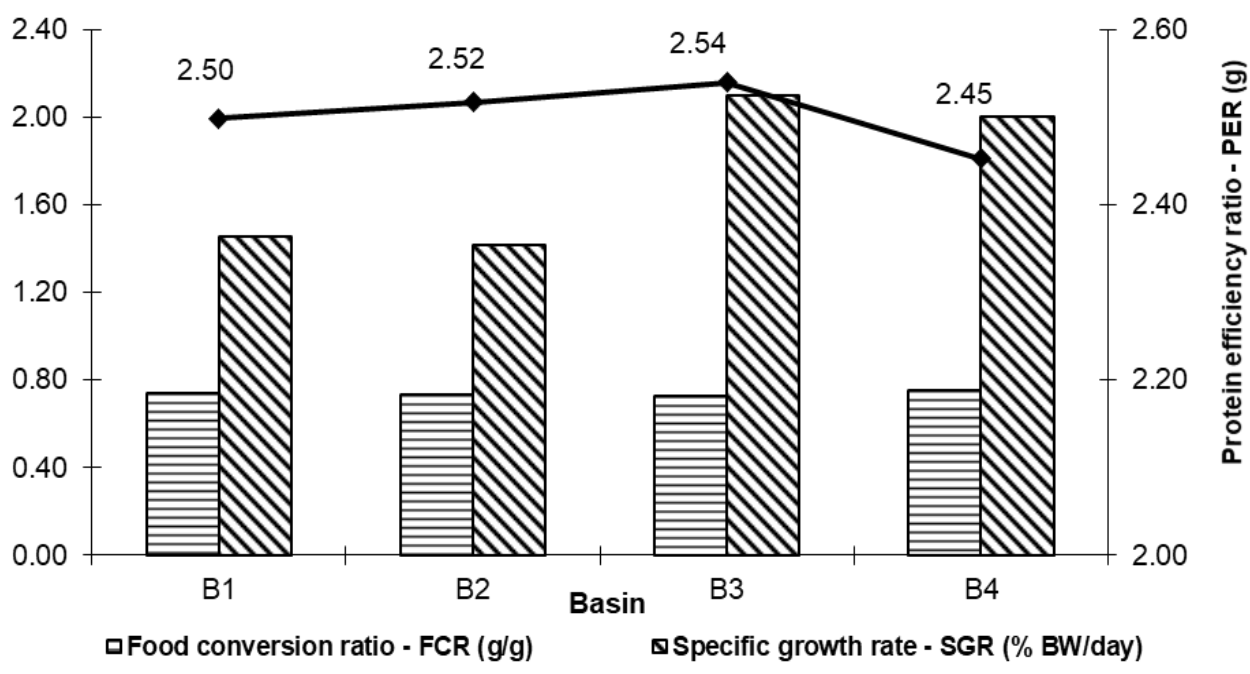

Figure 1. The growth performances of the Silurus glanis juveniles recorded at different feeding rates

but variant R2 was significantly higher (with 0.616 $\% /$ day) relative to $\mathrm{R} 1$ (T-test two sample, $\mathrm{p}=0.001$ ). Our data is close to those obtained by Havasi et al. (2015) who summarized, graphically, the means between 1.7-2.5\%/day into an experiment on European catfish juveniles weighting $59.9 \pm 12.9 \mathrm{~g}$ in the aim of assessing the effects of meals' frequency on fingerlings growth, fed with $2.5 \% \mathrm{BW} /$ day. In their trial, during 5 weeks, the SGR evolution patterns varied in a peculiar manner between the different treatments (continuous, 1 /day or $3 /$ day): remarkably different at the beginning of the trial and becoming quite equal to the end.

The close values of FCR between basins indicate that almost $74 \%$ of the food provided to the catfish during the trial was assimilated in body mass. Lower FCRs is related to high-quality feed and more efficient retention of the nutrients (Fry et al., 2018). This is the fitting situation in $\mathrm{R} 2$ feeding ratio, taken SGR into account, too, indicating the positive effect of the increased ration level $(2.5 \%)$ on growth at this life stage of catfish, due to the higher efficiency of transforming food energy for living tissues' construction. Also, sub-unitary values of FCR indicate less waste polluting the water and, in consequence, better water quality maintenance in the production system.

Also, the other parameter - PER (protein efficiency ratio) is considered one of the most popular means for quantifying the nutritional value of protein due to the fact that protein is the most expensive macronutrient in the fish diet with an economicimpactin production turnover. In our study,
PER presented almost a constant intergroups value of $2.50( \pm 0.04)$, indicating the higher efficiency with which the catfish have converted nutrients from feed into body mass and consequently, in nutrients for human food supply. Our results reinforced the data obtained by, Havasi et al. (2015) in the experiment presented above, on European catfish juveniles fed with a commercial diet having $49 \%$ crude protein, with good results of the feed intake (FCR $=0.77 \pm 0.07$, $\mathrm{PER}=2.7 \pm 0.2$ ) for the 3 times/day of the meal's frequency. In another study about four experimental diets with different percentages of protein, during a 112 days trial on European catfish fingerlings $(46,4$ g), Bekcan et al. (2006) obtained values quite similar to ours of the feed intake for the group fed with 40 $\%$ protein level $(\mathrm{FCR}=0.97 \pm 0.010, \mathrm{PER}=2.62 \pm$ 0.028 ), but smaller SGR $=0.74 \pm 0.002 \%$ /day in the conditions of ad libitum distribution of the food, twice/day.

Aproperfeedinglevel isanimportantcomponent for the success of European catfish production and must take into consideration besides the production system type, the fish life stage (Florczyk et al., 2014, Placinta et al., 2012), fish welfare (Dediu et al., 2010), the water's temperature and quality (Muscalu et al., 2010). For example, Florczyk et al., (2014) testing 3 diets containing different protein/lipid levels on smaller size of Silurus glanis fingerlings ( $4.2 \pm 0.15 \mathrm{~g})$, for 50 days, with continuous administration of the food (level feeding not specified, so supposing ad libitum) obtained, at the trial finish, the best results for SGR $(2.63 \pm 0.04 \%$ /day) in the group $45 / 20$, the most favourable PER $(2.36 \pm 0.14)$ in the group 
(37/12) even if FCR in all 3 groups $(45 / 20,45 / 15$ and $37 / 12$ ) was quasi-invariable. Placinta et al. (2012) obtained better production parameters for Silurus glanis fingerlings weighting $8.61 \pm 0.24 \mathrm{~g}$ (at a feeding rate of $6 \% \mathrm{BW} /$ day, $50 \%$ crude protein and a good quality water), such as: SGR - $3.52 \%$ /day, FCR 0.79 , PER-2.52. In the growth experiment presented by Muscalu et al. (2010), on one summer old Silurus glanis tested in 3 densities (mean fish weight ranged 36-37.8 g inter-densities), as an auxiliary species in a RAS for cultured sturgeons during the winter, observed that under $17^{\circ} \mathrm{C}$ fish don't consume the feed; but with the rise of temperature, the level of feeding increased gradually, so at $22{ }^{\circ} \mathrm{C}$ it reaches $2.5 \% \mathrm{BW} /$ day, like in our experiment. Also, in their system it was assesed a FCR between 1.20 (higher density) and 1.265 (lower density) in the conditions of a feeding accorded to appetite during the entire experiment.

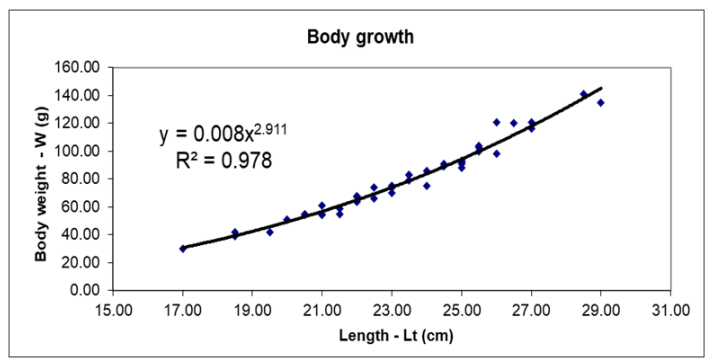

Initial fish condition from basin 1 (R1-1.5\%)

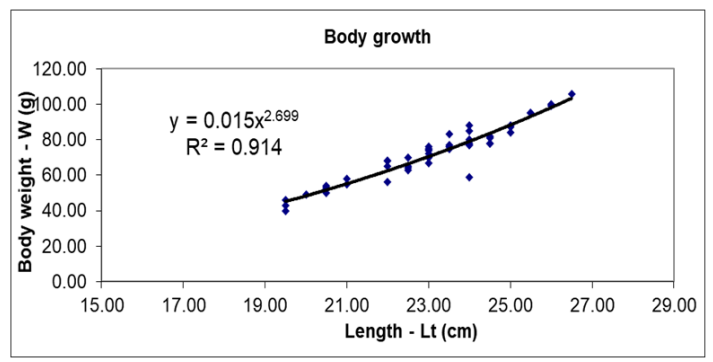

Initial fish condition from basin 2 (R1-1.5\%)

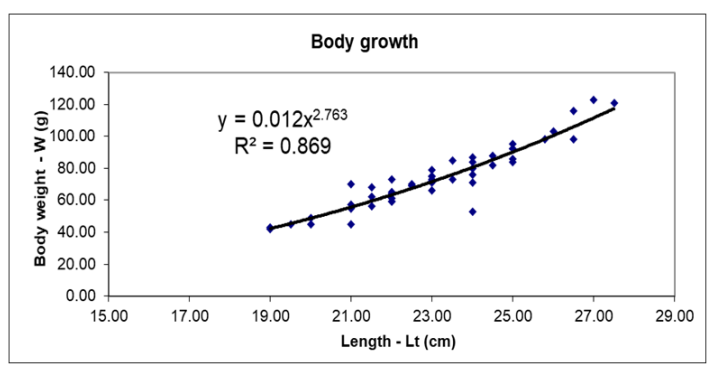

Initial fish condition from basin 3 (R2-2.5\%)

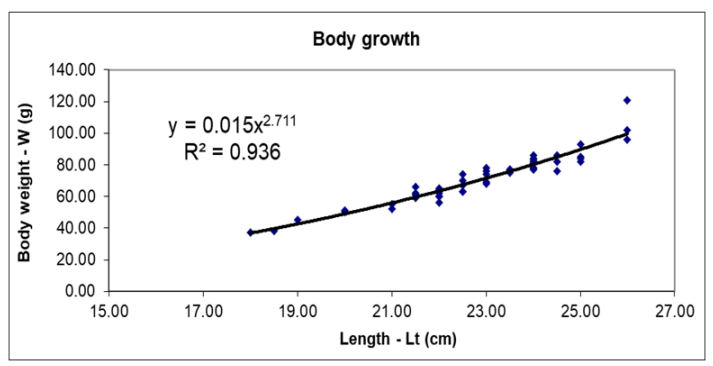

Initial fish condition from basin 4 (R2-2.5\%)

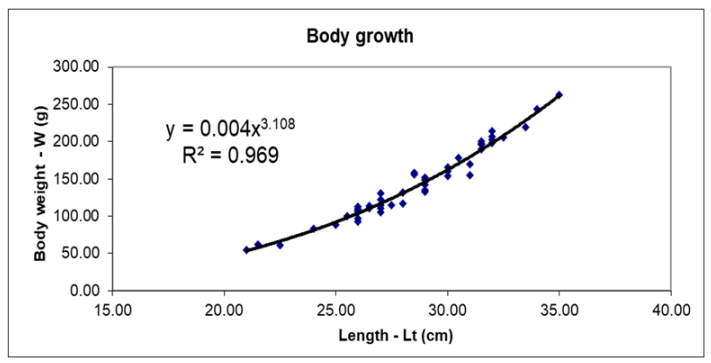

Final fish condition from basin 1 (R1-1.5\%)

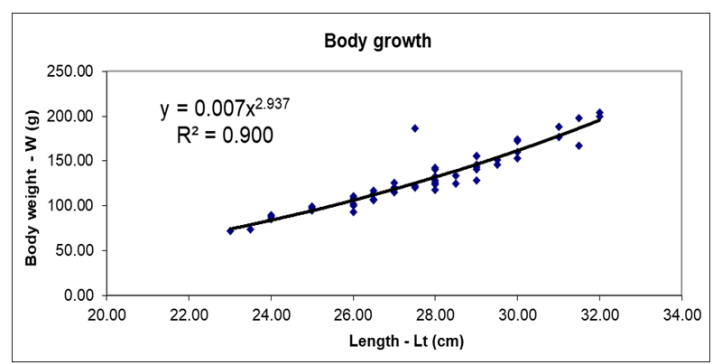

Final fish condition from basin 2 (R1-1.5\%)

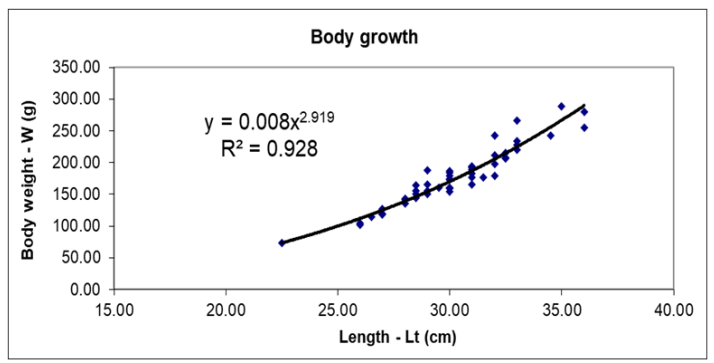

Final fish condition from basin 3 (R2-2.5\%)

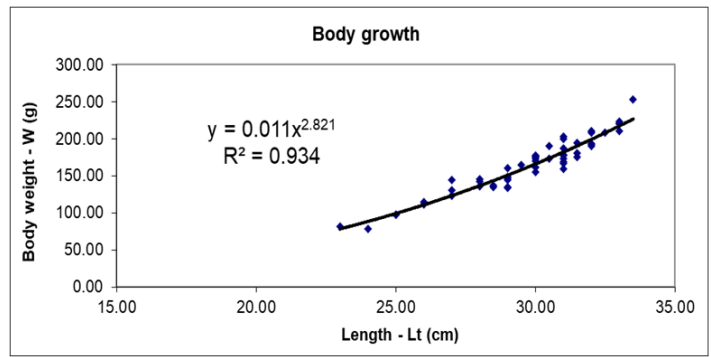

Final fish condition from basin 4 (R2-2.5\%)

Figure 2. The body growth expression revealed by the length-weight regression for Silurus glanis juveniles obtained at different feeding rates 


\section{Fish condition}

Silurus glanis has an elongated body that is laterally decompressed behind its broad head, which accounts for almost $20 \%$ of the entire body length (Copp et al., 2009), or less, depending on fish age (Măgdici et al., 2014; Arteni, 2010). In their paper review, Copp et al. (2009) point out that the growth of Silurus glanis in natural environment is most intensive in the first year of life when the yearlings can reach a total length of $38-48 \mathrm{~cm}$ and it is highly variable as adaptation to the different diet and environmental conditions (geographical habitat, water temperature, food abundance etc.).

In the current study, we used the length-weight relationship to assess the fish condition among the experimental groups assuming that heavier fish at a given length is in better condition after the feeding treatments. Determining the exponent " $b$ " and the difference from " 3.0 " value indicates the direction of condition changes. As in other fish species, $b<3.0$ indicates a decrease in condition or elongation in form, $b>3.0$ indicates an increase in the condition when the increase in weight exceeds the increase in length. The larger the difference from 3.0, the larger the change in condition or form. Also, the determination coefficients $\left(\mathrm{R}^{2}\right)$ was computed for suggesting the percentage of weight gain that can be attributed to the length increment.

The variation of the condition factor among the experiment, as well as the determination coefficients $\left(R^{2}\right)$, are presented in Figure 2.

From the "condition factor" point of view, a slight improvement of the nutritional status at the end of experiment in all basins could be observed. The inter-variants analysis indicates that, apparently, the individuals from the $\mathrm{R} 1$ feeding level have a better approach (mean "b" value was 3.023 compared with 2.870 in R2, at the end of the experiment). Correlating with the similarity of the recorded $\mathrm{R}^{2}$ values, this situation suggesting a possible competition for food even in the experimental variant with higher feeding rate R2. Taking into account our results reported to those found by Havasi et al. (2015), the continuous repartition of the daily food could be a better solution for catfish feeding because, besides elevated feeding rates, increasing the feeding frequency could be the answer in order to obtain a homogenous population in aggressive specie like Silurus glanis. The coefficient of variation (CV \%) recorded a larger variation by analysing the final moment (R1, $27.73 \% \rightarrow 30.34 \%$ $>\mathrm{R} 2,23.87 \% \rightarrow 24.44 \%$ ). For this predatory species,
Zaikov at al. (2008) found for one summer old fish raised in ponds a considerable variation (153.33\%), explained either by the individual variability within the limits of its species or as results of the specific growing conditions.

\section{Conclusion}

Determining the optimum feeding level in accord with the age is important to maximize the fish growth and feed use efficiency because the feed costs are the greatest operating expense in fish farming so the economics of feed conversion is therefore of high importance. Our results regarding the growth performances of the one summer old European catfish, expressed by production parameters SGR, FCR and PER, indicated a good increment of the biomass weight in parallel with the increasing of the feeding level. Usually, the high growth rate increases production turnover because a fast-growing fish will reach in advance the market size. The analyze of the fish condition during our experiment underlines the importance of applying a proper feeding frequency, too, in order to minimize the size differences within the population. As a voracious fish with a larger mouth, European catfish can magnify any initial advantage in size through competition in food, resulting in biased subpopulations (the R1 experimental variant's case). The use of the self-feeders for this species seems to be a better operating action for increasing the feed acquisition, resulting in a more homogenous population and better feed management, too.

Acknowledgments. This work was supported by the project "EXPERT", financed by the Romanian Ministry of Research and Innovation, Contract no. 14 PFE/17.10.2018. The authors are grateful for the technical support offered by MoRAS infrastructure through the Grant POS CCE ID 1815, cod SMIS 48745 (www.moras.ugal.ro) and the project PN I BIOTECH Sitsom 121/2006.

\section{References}

1. Arteni MO (2010). Comparative study of some indices and body coefficients of Silurus glanis and Cyprinus carpio in different stages of development. Lucrări Științifice - Seria Zootehnie, 54, 326-331.

2. Bekcan S, Dogankaya L, Cakirogullari GC (2006). Growth and body composition of European catfish (Silurus glanis L.) fed diets containing different percentages of protein. The Israeli Journal of Aquaculture - Bamidgeh 58(2), 137142. 
3. Bregnballe J (2015). A Guide to Recirculation Aquaculture. An introduction to the new environmentally friendly and highly productive closed fish farming systems. Published by the Food and Agriculture Organization of the United Nations (FAO) and EUROFISH International Organisation, http://www.fao.org/3/a-i4626e.pdf / Accesed 05.04. 2019

4. Copp GH, Britton JR, Cucherousset J, Garcia-Berthou E, Kirk R, Peeler E, Stakenas S (2009). Voracious invader or benign feline? A review of the environmental biology of European catfish Silurus glanis in its native and introduced ranges. Fish and Fisheries, 10, 252-282, https://invasiber. org/GarciaBerthou/docs/papers/Copp_etal_FF_09.pdf / Accesed 05.04. 2019

5. Dediu (Sfetcu) L, Docan A, Cristea V, Grecu I (2010). Considerations regarding the rearing of european catfish, Silurus glanis L. in a flow-through production aquaculture system. Lucrări Ştiinţifice - Seria Zootehnie, 53, 284-288.

6. Florczyk K, Mazurkiewicz J, Przybylska K, Ulikowski D, Szczepkowski M, Andrzejewski W, Golski J (2014). Growth performance, feed intake and morphology of juvenile European catfish, Silurus glanis (L.) fed diets containing different protein and lipid levels. Aquacult Int., 22, 205214, DOI 10.1007/s10499-013-9667-0.

7. Fry JP, Mailloux NA, Love DC, Milli MC, Cao L (2018). Feed conversion efficiency in aquaculture: do we measure it correctly? Environ. Res. Lett. 13024017 https://doi. org/10.1088/1748-9326/aaa273/ Accesed 28.03.2019

8. Havasi M, Kumar S, Nagy Z, Beliczky G, Nagy S, Bercsényi M, Gál D (2015). Effects of feeding regime on growth feed conversion and size variation of Silurus glanis. Croatian Journal of Fisheries, 73, 142-147

9. Hilge V (1985). The influence of temperature on the growth of the European catfish (Silurus glanis L.). Journal of Applied Ichthyology, 1(1), 27-31, https://doi. org/10.1111/j.1439-0426.1985.tb00407.x.

10. Linhart O, Stech L, Svarc J, Rodina M, Audebert JP, Grecu I, Billard R (2002). The culture of the European catfish, Silurus glanis, in the Czech Republic and in France. Aquat. Living. Resour., 15 (2), 139-144,
11. Măgdici E, Pagu IB, Nistor CE, Iordache MI, Hoha GV, Păsărin B (2014). Study on the evolution of some morphological characteristics of Silurus glanis species in different development stages, farmed in Iasi county. Lucrări Ştiinţifice - Seria Zootehnie, 62, 79-84.

12. Mocanu (Cretu) M, Cristea V, Dediu L, Dicu D, Docan A, Ionescu $\mathrm{T}$ (2011). The influence of different stocking densities on growth performance of Oncorhynchus mykiss (Walbaum, 1792) in a recirculating aquaculture system. Lucrări Ştiinţifice - Seria Zootehnie, 56 (16), 326-331.

13. Muscalu R, Muscalu C, Nagy M, Bura M, Szelei ZT (2010). Studies on wels catfish (Silurus glanis) development during cold season as an auxiliary species in sturgeon recirculated aquaculture systems. AACL Bioflux, 3(5), 362-366.

14. Plăcintă (Ion) S, Cristea V, Grecu IR, Mocanu (Creţu) M, Coadă MT, Antache A, Bocioc E, Petrea ŞtM (2012). The influence of stocking density on Silurus glanis (Linnaeus, 1758) growth performance in a recirculating aquaculture system. Lucrări Ştiinţifice - Seria Zootehnie, 58, 306-310.

15. Silva SS, Anderson TA (1995). Energetics, Fish nutrition in aquaculture. London. Chapman \& Hall, 15-25 p.

16. Timmons MB, Ebeling JM, Wheaton FW, Summerfelt ST, Vinci BJ (2002). Recirculating Aquaculture Systems, 2nd Edition. Publisher Cayuga Aqua Ventures Llc, pp. 19-50, 505-562,

17. Vasilean I, Cristea V, Sfetcu L (2009). Influence of stocking density and water parameters on growth of juvenile beluga sturgeon (Huso huso, Linnaeus, 1758). Lucrări Ştiinţifice - Seria Zootehnie, 52, 666-671.

18. Woynarovich E, Horváth L (1980). Propagation of European Catfish (Silurus glanis). In The artificial propagation of warm-water finfishes - a manual for extension. FAO Fisheries Technical Paper No. 201. FAO, Rome, Italy: $183 \mathrm{pp}$

19. Zaikov A, Hubenova T, Iliev I, Vasileva P (2008). Body length and body weight ratio characteristics of onesummer - old wels (Silurus glanis L.). Bulgarian Journal of Agricultural Science, 14 (2), 176-181. 